\title{
Towards Disaster Management in Indonesia Case Studies: Jakarta and Yogyakarta Provinces*
}

\author{
Yuni Reti Intarti ${ }^{1}$, Irene Sondang Fitrinitia ${ }^{1}$, Muhammad Rahmat Widyanto ${ }^{2}$ \\ and Hendricus Andy Simarmata ${ }^{1}$ \\ ${ }^{1}$ Urban Studies, Postgraduate Program, Universitas Indonesia \\ Jakarta, Indonesia \\ ${ }^{2}$ Faculty of Computer Science, Universitas Indonesia \\ Jakarta, Indonesia
}

\{intarti,irene.sondang\}@ui.ac.id; andibanjar@yahoo.com\},widyanto@cs.ui.ac.id

\begin{abstract}
Based on the Asia Pacific Disaster Report prepared by the UN International Strategy for Disaster Reduction (UN/ISDR) and the UN Economic Commission for Asia and the Pacific (ESCAP) on 26 October 2010, during 1980-2009 period in Asia Pacific countries, Indonesia was the fourth rank of the highest natural disasters for about 312 cases, second rank of the highest number of death approximately 191.164 people, and also had economic losses for at least US\$22.5 billion. The geographical location, archipelagic region, tectonic formation, largest population, and tropical climate condition have put Indonesia into the highest disaster risks of tropical geo-hazards as well as earthquakes, volcanic eruptions, landslides, floods, and forest fires. How Indonesia deals with the natural disasters is very important issue nowadays not only for the government but also for academia to produce knowledge related to disaster management. The availability of disaster management planning was extremely important to have proper disaster management. This paper provides the experiences of Indonesian cities in conducting disaster management planning processes through two case studies Jakarta and Yogyakarta. This study found that the disaster management plan in both cities considered the level of risks, not only the level of disaster impacts through risk mapping process. The different size of city also brought the different way of mapping and planning processes. These findings suggest that contrary to rational comprehensive planning, which solely conducted by the experts, the disaster management planning should be conducted inclusively through collaborating among government, experts, and vulnerable groups.
\end{abstract}

Keywords: urban, disaster, management, planning

\section{Introduction}

World growth is like two sides of coin nowadays. Besides it has progress of great development to achieve human prosperity, the world also is dealing with disasters that occur to impact its welfare. Hewitt (1995) claimed if there could be such a thing as sustainable development, disasters would represent a major threat to it, or a sign of its failure. That scepticism statement must be tackled with efforts to the disaster risk reduction.

\footnotetext{
* It has been reviewed at 2011-2012, organized by between Urban Study, University Indonesia and National Disaster Management Agency with title : "Disaster Risk Mapping in 9 Provinces in Indonesia " this paper also presented on academic conference of ISCIIA2012 (the International Symposium on Computational Intelligence and Industrial Applications) on 20-26 August 2012 in Hokkaido, Japan
} 
On the other hand the rapid population growth put heavy pressure on space. If it is not managed properly it will create a potential risk of hazard. Within population reaching nearly 6 billion in 2012 (United Nation Statistics Division), apparently our planet is experiencing the problem by increasing the risk of disaster. Type of disaster includes natural hazard or even man made hazard disasters often occur anywhere in the world.

Talking about disaster, we must think about risk terminology with consist of hazard, vulnerability and capacity. Disaster losses are caused by interactions between hazard events and the characteristics of exposed elements that make them susceptible to damage. A hazard's destructive potential is a function of the magnitude, duration, location and timing of the event (Burton et al., 1993). To be damaged, however, elements exposed to a given type of hazard must also be vulnerable to that hazard; that is, the elements must have intrinsic characteristics, or vulnerabilities, that allow them to be damaged or destroyed (UNDRO 1979).

In Asia particularly, we have many severe tremendous disaster with high casualties and damages. It is not only natural hazard that threaten people's life, but man-made hazard also poses a threat. Eight years ago, in 2004 we still remember how Asia Pacific was hit by earthquake and horrible tsunami. In 2006, we had typhoon in Philippine or man-made hazard like war in Iraq (suddengly shift to Middel East?).

From the facts given above we learn about the massive impact and how important to handle it with disaster risk management. It is based on identification of latent causal factors, it can help inform efforts to intervene to reduce risks and therefore losses before such losses occur. Making risks foreseeable provides motivation for risk reduction (Glantz, 2002). Identification of risk factors creates possibilities for shifting emphasis from reliance on relief and reconstruction following disasters towards prevention of losses and preparedness to reduce recovery time following disasters. Risk assessment, reduction and transfer are the major elements of risk management (Kreimer et al., 1999), a desirable alternative to managing disasters through emergency management.

Disaster management is similar to disaster mitigation; however it implies an entire government approach to use community resources to fight the effects of an event and assumes the community will be self-sufficient for periods of time until the situation can be stabilized. Through disaster management, we cannot completely counteract the damage but it is possible to minimize the risks through early warning, provide developmental plans for recuperation from the disaster, generate communication and medical resources, and aid in rehabilitation and post-disaster reconstruction.

\section{The Research of Disaster Impacts}

The risk mapping must mainly identify three key variables:

1. The possibility of hazard $(\mathrm{H})$

2. The Vulnerability factor (V), and;

3. The Capacity to deal with $\mathrm{C}$,

Then we will have the RISK as: $R=(H \times V): C$

\section{Situation and Condition in Indonesia}

What about Indonesia? As one of developing countries in South East Asia, Indonesia has had a lot of experience with disaster. Physical and social factors are the main cause to increase the risk. Overall Indonesia has 11 categorized as disasters based on Act Number 24 of 2007 about Disaster Management, which include: earthquake, tsunami, volcano, flood, 
drought, hurricane, landslide, technology failure, epidemics and outbreak of disease, social conflict and terrorism.

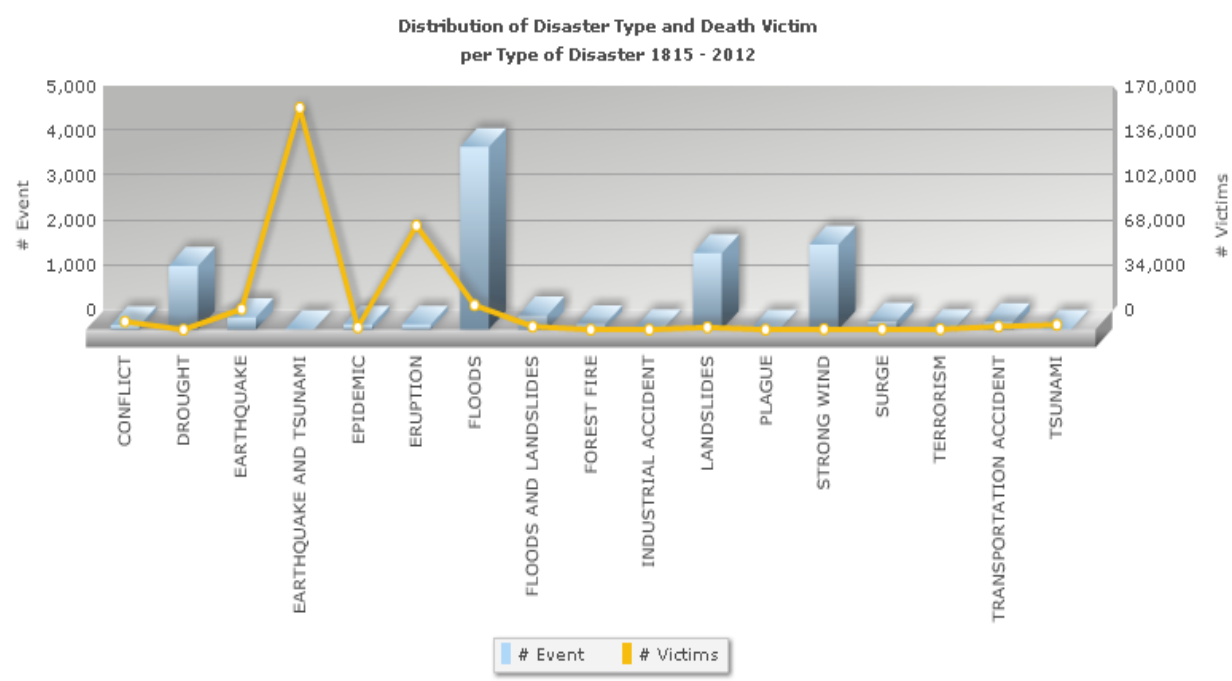

Source : BNPB Data, 2012

\section{Chart 1. Distribution of Disaster Type and Death Victim per Type of Disaster 1815 - 2012}

From the chart above, we could see tsunami is a disaster that claimed most victims than other form of catastrophes from 1815 until 2012 in Indonesia. Specifically, it happens after the tsunami in Aceh in 2004. But we could also see flood is the most frequent disaster with 4000 events in Indonesia. But natural disaster triggered by human technical system error is Sidoarjo mudflow or Lapindo mud has been in eruption since 2006 till present was making the biggest mud volcano in the world.

a. Physical and Social Portraits of Indonesia

Physical factors, which are geology and geomorphology condition of Indonesia, can describe how Indonesia becoming prone risks area. Indonesia is an archipelago consisting of 17000 islands and its located at the latitude of the equator to its own characteristics that could potentially increase the risk of threats.

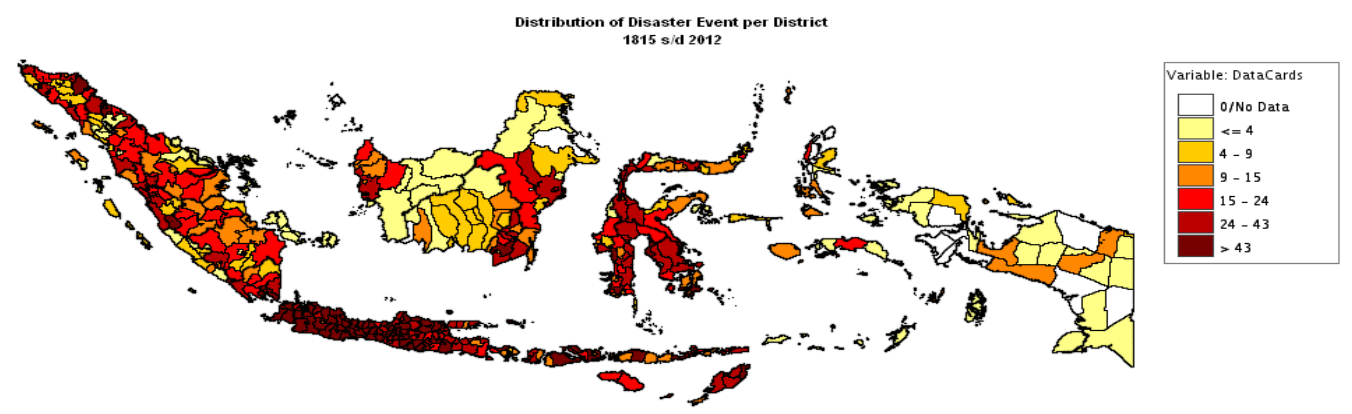

Source : BNPB Data, 2012

Figure 1. Distribution of Disaster Events per District 1815-2012 


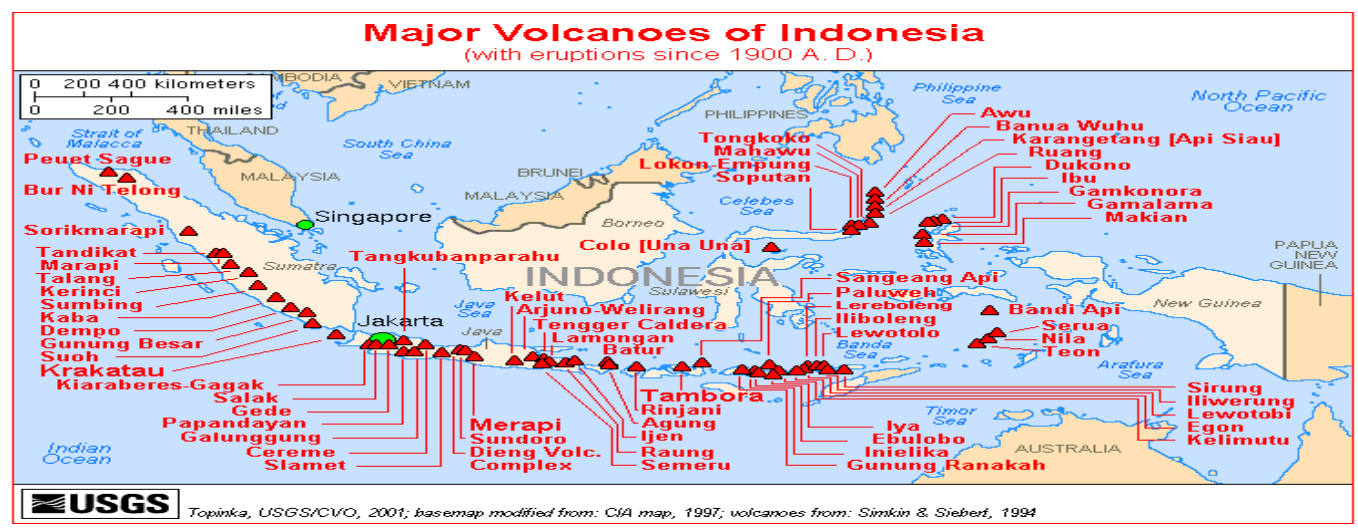

Source : BNPB Data, 2012

Figure 2. Distribution of Volcanoes (Ring of Fire) in Indonesia

In addition, Indonesia is the path ring of fire, with more than 90 volcanoes, has a high annual rainfall and crossover by 5,950 river basin area. These characteristics make Indonesia being a country that fertile and rich in natural resources.

Meanwhile social factor include demography and economy condition is described as an important thing, Indonesia as multicultural country. Indonesia with GDP higher than international average GDP in 2012 approx. US\$ 846 billion has become the country with the biggest population in Southeast Asia, also the 5 biggest ranks in the world.

Other than its high productivity and large population, the country is experiencing the problems of uneven distribution of the density because the economic activities and urban settlement only concentrate in the island of Java. Therefore, the problem of Java, like disaster events, indirectly becomes national concern due the socio-economic reason.

\section{b. Disaster Management Policy of Indonesia}

The policy snapshot of disaster management occurs from the history of institutional arrangement in Indonesia. The official institution, which charged with matters relating to disaster, is the National Disaster Management Agency, in bahasa Badan Nasional Penanggulangan Bencana (BNPB). Since it was inaugurated in 2008, this institution had a lot of homework because disasters was frequently occurred as catastrophic event, ones of the biggest are the tsunami in Aceh (it was 2004) or earthquake in Yogyakarta in 2006.

Prior to BNPB, the government of Indonesia had several institutions already in place to manage natural disasters. It was begun with the institution that take care of independent victims at 1945 shifting to reduce natural disaster at 1966, has been change several times as ad-hoc institutions, until formed as a coordination agency in early 2000, and then finally defined as a permanent institution, namely BNPB as an implementation of the act 24/2007 regarding Disaster Management (see Figure 3). 


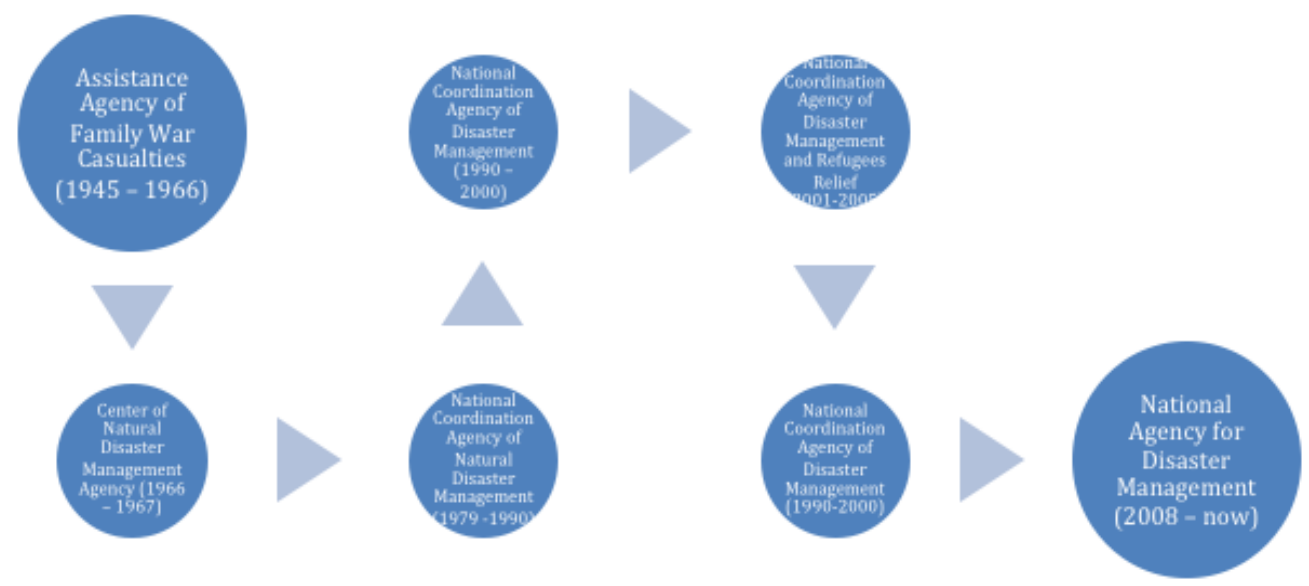

Source: BNPB, 2012

\section{Figure 3. Disaster Management Institution Changes}

The missions of BNPB are to protect nation from the threat of disaster through building reliable system of integrated and comprehensive disaster management. This has been mandated in Act Number 24 of 2007 about Disaster Management and BNPB must create programs refer to that. BNPB existence cannot be separated with derivative institution such as Regional/Province Disaster Management Agency (BPBD) although it is vertical coordination to the central institutions (BNPB), but also consider to local/province policy that reflect the spirit of local authorities.

The content of legal products regarding disaster management describes the stages of management comprehensively. It is started from preparedness, response, recovery also mitigation and prevention to disaster in the time of pre, during, and post-disaster.

In practice, the government of Indonesia plays the main role to manage disaster risk from policymaking until the implementation, and evaluation.. The Government put BNPB in the national level and BPBD in the local level as a focal point for several cross cutting government institutions, such as ministry of public works, ministry of transportation, geophysical and meteorological agency, etc.; and other development stakeholders, such as NGO, private sector, and civil society, etc. This type of centralized institution is expected to make the management of disaster can be run efficiently, effectively, and properly.

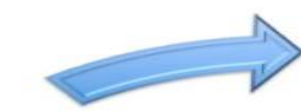

Recovery

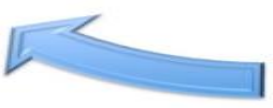

Mitigation and Prevention

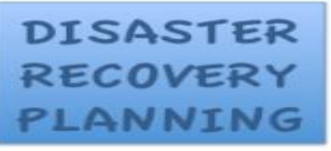

Response

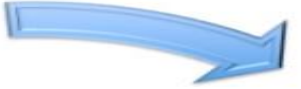

Preparedness

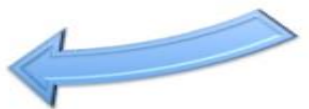

Source: BNPB, 2012

Figure 4. Disaster Recovery Planning Cycle 


\subsection{Flood Management in Jakarta}

Massive development will have side effects if managed improperly. Jakarta is an example of dense cities that faces wicked disaster problem. It means beside of the natural disaster events, Jakarta has already had problem in controlling massive development, which can potentially led to environmental degradation and will exacerbate the impacts of disasters.

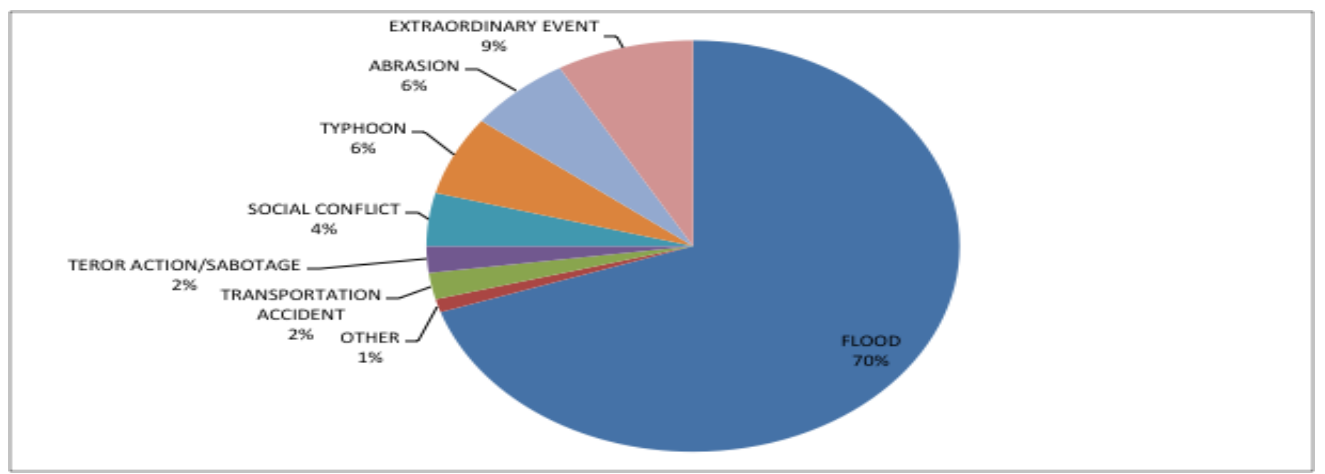

Source: $B N P B, 2012$

Chart 2. Type of Disaster in Jakarta

One of the major disasters is flood. According to BNPB (2012), almost 63\% flood incidents during several years surpass other type of disaster is flood (see chart 2).

It has lasted for decades. Whereas, the flood infrastructures, such as east and west canals, have already built in 2010, but still Jakarta has many places flooded. Even, until this paper written, most of Jakarta area is still hit by annual flood, particularly in Kampung Melayu in East Jakarta and Penjaringan in North Jakarta (see Figure 5).

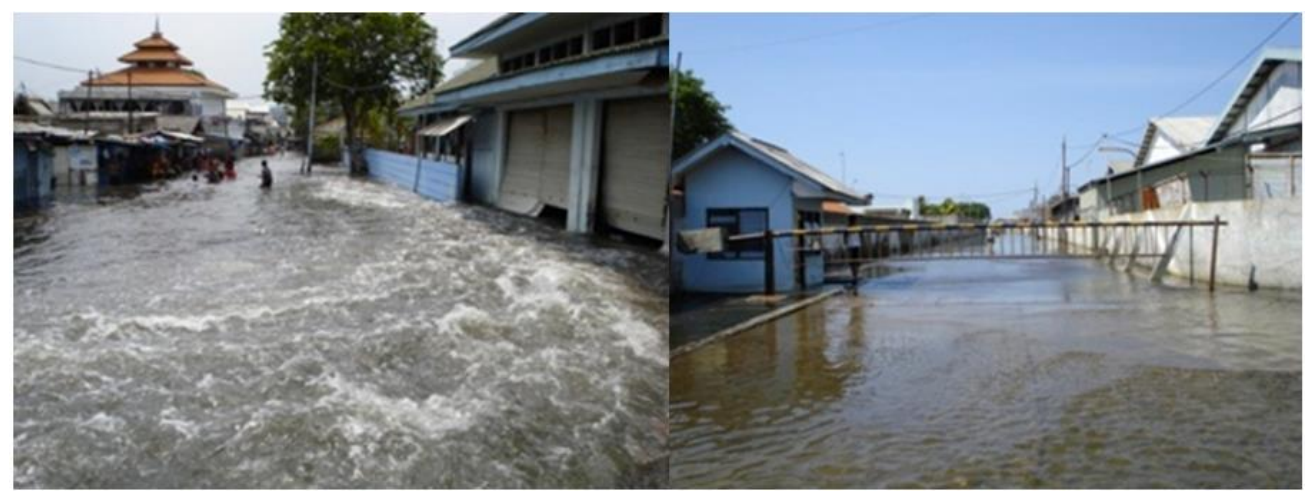

Figure 5. Photo of Flood in Jakarta

Based on the BNPB regulation, the disaster management should be taken based on the disaster management plan or rencana penanggulangan bencana (RPB). RPB is a master plan for government agencies to conduct the program and for other stakeholders to participate in the disaster management program. RPB is made based on three levels of impacts, which are macro (national) level, mezzo (provincial) level, and micro (city level). In the case of Jakarta, the draft RPB for provincial level is already established, but for micro level is in the process. 
RPB consists of two main substances, risk mapping and planning. As noted previously, to manage disaster properly, it should be explained by risk concept. Risk is determined by level of hazard, vulnerability and coping capacity. So, risk mapping is a superimposed map of hazard, vulnerability, and coping capacity.

Based on the risk mapping at the mezzo level, we could figure out that the level of vulnerability of Jakarta was relatively high (see Figure 6). The flood hazard was mainly located in north to central and east Jakarta since physical characteristic (being located at the mouth of the river) and poor sanitation make this area frequently flooded.

Almost $40 \%$ of Jakarta particularly in northern area lies below the sealevel. The most vulnerable area that was determined by Vulnerable group (elderly, infant, and disabled), green spaces proportion, and availability of public as well as private facility, is located in the north side of Jakarta (Cilincing and Klender). Both areas have the highest proportion of vulnerable group, which reach $20 \%$ from population and always lose substarial assets everytime floods hit Jakarta. In the other hand, the coping capacity of Jakarta, which measured by the government institutional capacity, is relative good. Since Jakarta has already Disaster Management Agency of DKI Jakarta Province (BPBD) since 2011.

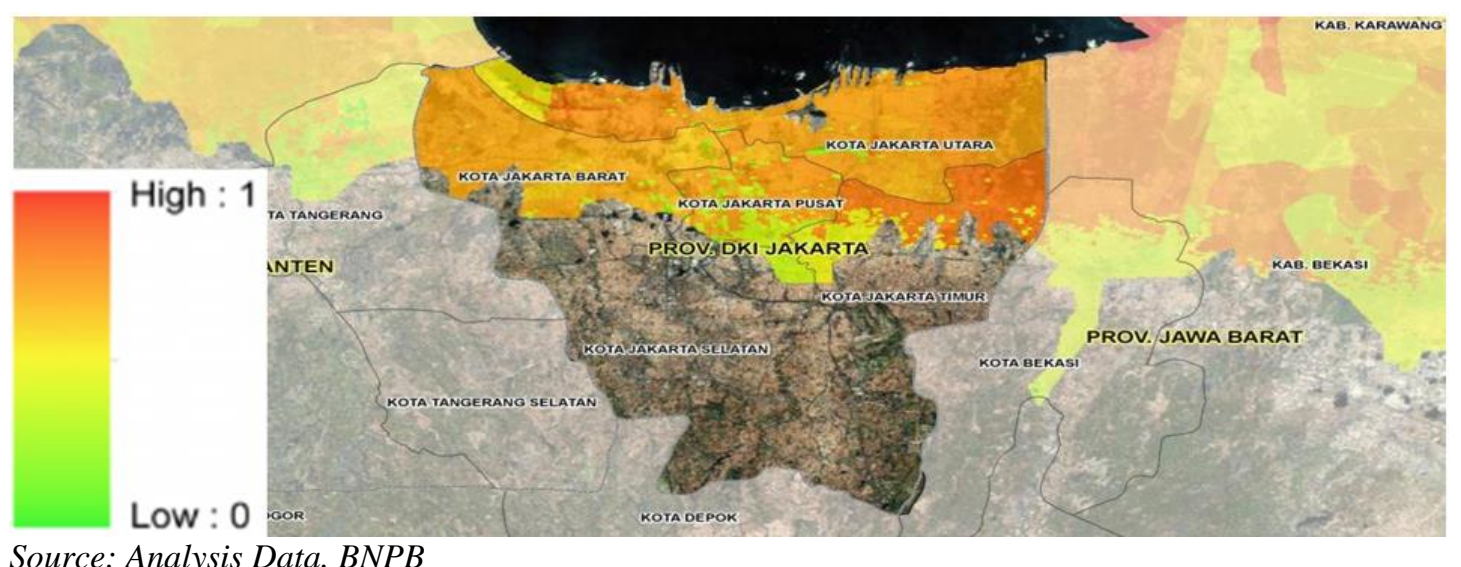

Figure 6. Map of Flood Risk in Jakarta

But, still BPBD needs time to coordinate among 20 local institutions owned by government and private sector. BPBD DKI Jakarta does not have sufficient integrative (spatial) data or regulation to be used to have proper policies, planning, and program for reducing disaster risk at present. However, BPBD Jakarta is now conducting risk mapping and the disaster management plan (RPB) for the next 5 years, which include flood in the management plan.

The disaster management affairs in Jakarta are changing in several periods (see Figure 7). Based on the picture, we could see the changing of institutional changing in Jakarta is not only organizational structure, but also the function of organization. BPBD enhances its goals by focusing on risk reduction in holistic way. There are five objectives which covers:

1. Strengthening legislation and institutional capacity; increaseing coordination with the drafting of region regulations on disaster, etc.

2. Integrated Mitigation Plan; development of an integrated logistics distribution, etc.

3. Research, Education and Training; implementation of curriculum about disaster at schools, etc. 
4. Increased capacity and participation of stakeholders; optimal application of technology by stakeholders, etc.

5. Protection of society from disaster: Construction of multi-disaster early warning system, etc.

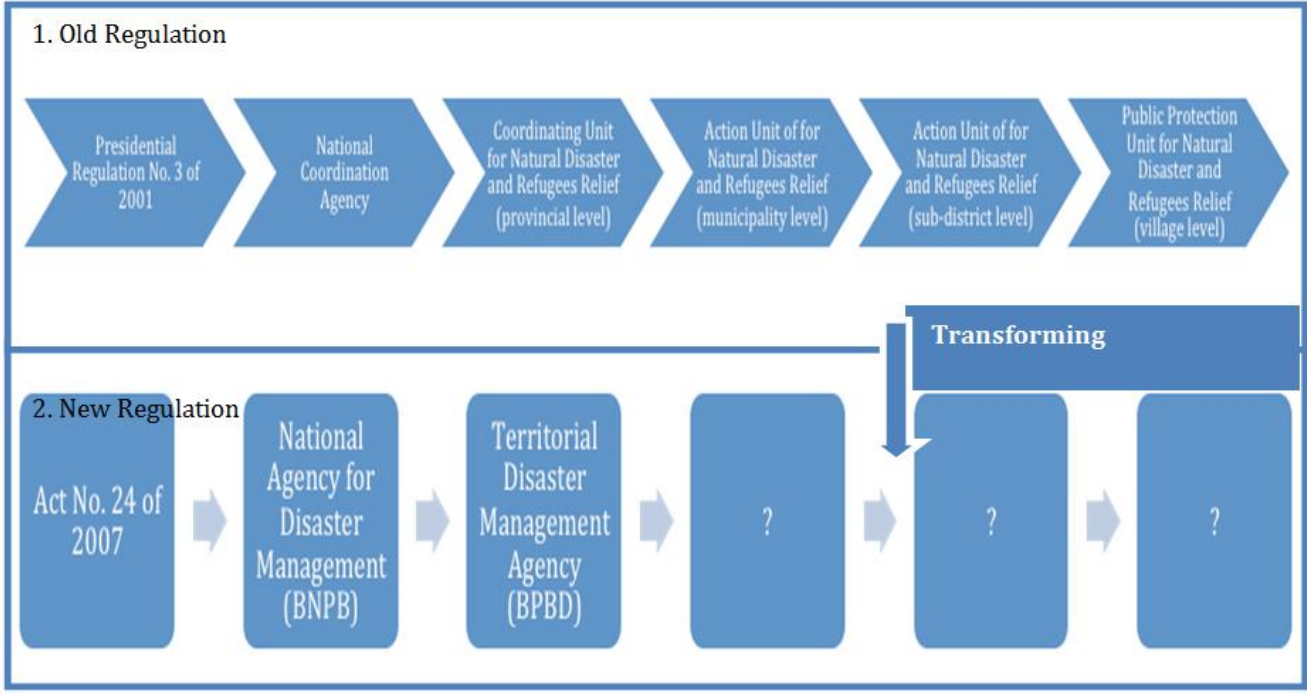

Source: modified from $B N P B, 2012$

Figure 7. Institutional Changing of Disaster Management in Jakarta

And the last findings, nowadays BPBD integrates its plan, which is Disaster Mitigation Plan (RPB), into the Medium-Term Development Plan (RPJMD) and annual development program (RKA-T). BPBD put the minimum targets of government budget allocation is for about $1 \%$ of provincial budget plan in every fiscal year. It is expected will change the old paradigm to respond, to be new one, managing the risks.

\subsection{Earthquake Management of Jogyakarta}

An earthquake (also known as a quake, tremor or temblor) is the result of a sudden release of energy in the Earth's crust that creates seismic waves. As condition of geomorphology in Indonesia, earthquake happens in this country. Many factors could be attributed to it: the fact that Indonesia lies on the three plates (Eurasian, Indo-Australian and Pacific Plate). Around the location of the meeting is the accumulation of plate collision energy accumulated up to a point where the layers of the earth is no longer able to hold off the stack so that the energy of an earthquake is released.

The tectonic condition below has brought the earthquake disasters into Yogyakarta with the magnitude 6.3 S.R. in 2006. This incident resulted in more than 5000 people as victims and the damage of 370,776 units of private and public infrastructures (Public Works Ministry, 2006).

Shortly after an earthquake hit Yogyakarta, it became becoming chaos. At that time, disaster was not yet organized. The contribution of each element of society, both from the government, private sector, and international agency took place with minimal coordination. Learning from this, Yogyakarta has drafted RPB and province action plan with participatory approach. 
Based on the risk mapping and RPB of Yogyakarta, it can be shown that the hazardous area of earthquake located in centre to south, went to Bantul region. The possibility of this hazard include in "medium" category. The vulnerable group in dealing with earthquake is about $30.1 \%$ from population of Yogyakarta region. Moreover, beside an existence of vulnerable group, the most severe location is at south and east of Yogyakarta caused by density and loss of lot assets.

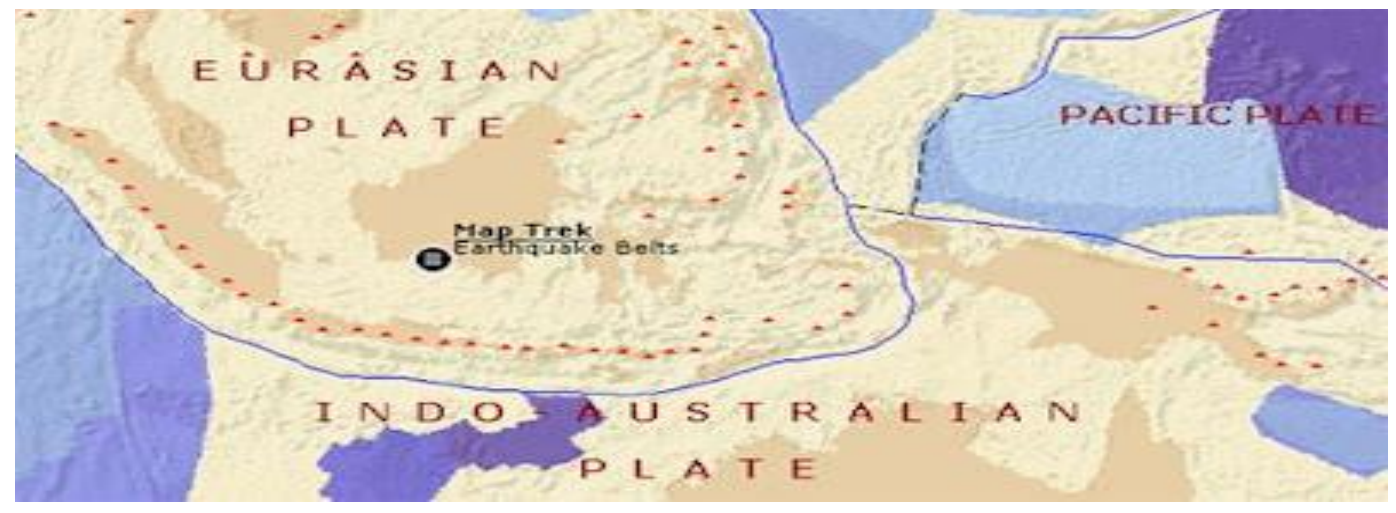

Source: BNPB, 2012

Figure 8. Plates in Indonesia

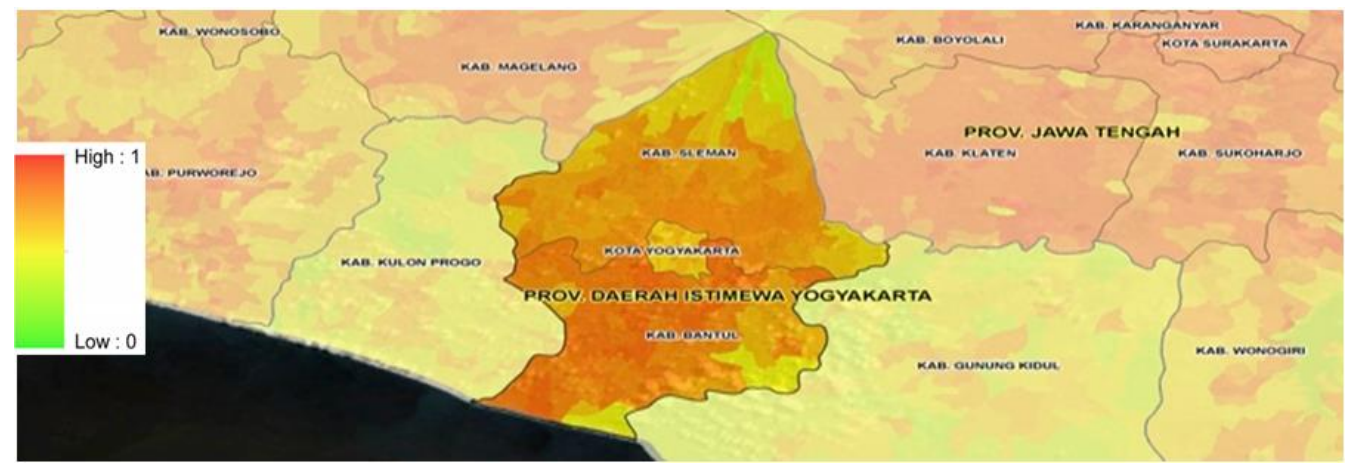

Source: Analysis Data, BNPB

Figure 9. Map of Earthquake Risk in Yogyakarta

Beside hazard and vulnerability, the coping capacity is important because it manifested as physical product, strategy mechanism or even policies. Yogyakarta has already institution and mechanism in place for coping disaster management. Not only earthquake but also other type of disaster, BPBD Yogyakarta is very intense as a coordinating institution to interact with local and international NGO. There is also policies like Local Regulation No. 8 Year 2010 Implementation of Disaster Management at Province Level, Regulation of the Governor of DIY No 49 of 2011 on the Standard Operating Procedures for Disaster Management. Therefore, based on the overlaying of three variables hazard, vulnerability and capacity, we know about risk possibility of earthquake in Yogyakarta is described like picture below. Risk of earthquake comes up in South of Yogyakarta which is Bantul also part of Sleman. 
BPBD Yogyakarta has also formulated the RPB based on the risk mapping above. The management planning has focused on the management cycle, which stated as follows:

- Pre Disaster: Compilation of integrative procedure operational, training and drilling to local government staff, private sector and society, re-manage building and land use (resistant to earthquake).

○ Response: Implementation of an integrated contingency plan, rescue and evacuation, etc.

○ Post Disaster: psychological rehabilitation, infrastructure development, etc.

The risk mapping and RPB processes in Yogyakarta has also shown the experiences of government in conducting the process inclusively. The participation from the other stakeholders, such as academia and NGOs is the main different way, compared to Jakarta.

\section{Lesson Learnt from the (RPB) Planning Processes}

In disaster management, mitigation means taking actions to reduce the effects of a hazard before it occurs. Mitigation is the important element as consequence for those who lived at prone area. Who are they? Every layer of society must be contributing to reduce disaster impact.

Who are they? Every layer of society must be contributing to reduce disaster impact. We need real cooperation between government (local and national) and non-government agencies, such as private sector, NGO and until local community.

The capacity for local or municipal government to contribute to building resiliency is greatly determined by its organizational structure and relationship to national government (Solway, 1994). Disaster preparedness starts at the local community level; If local resources were insufficient, it would branch out to the national level, and if needed, the international level. Mitigation is an activity carried on by all roles. So, it can summarize that mitigation must be integrated between government and society and the activities carried on by all role between them.

For the case of Jakarta and Yogyakarta, the role of the community in the disaster management planning process is quite diverse. These two provinces differ in terms of aspects of society to cope with disasters. It is influenced by the characteristics of the region and institutional capacity of government.

Jakarta, the biggest city in Indonesia, cannot expect the active intervention from the entire society. It always depends on the representative mechanism. It is represented by the NGOs or other civil societies whom have concern about the flood. They established the communication forum, namely Forum Peduli Banjir, which brought the voices of vulnerable group when disaster management planning processes or other related activities conducted. Considering the general typical of metropolitan city, which is more individualistic, solidarity mechanism seen only at community level, not applied at the mezzo level, even micro level,

While the province of Yogyakarta is not as big as Jakarta, along with the experience of the Yogyakarta disaster massive impact, Yogyakarta is a step forward compared to Jakarta. Yogyakarta has relatively more disaster mitigation experience that leads to disaster issues becoming mainstream in every activity. Strong pressure comes not only from government movement, but also from local and international NGO. Type of a community that is more heavily influenced by nature of collectiveness, mutual care and responsive public towards problem.

Based on both cities, the planning process are strongly driven by government interests. Comparing the role of each government in implementing the RPB processes, Yogyakarta has 
more completed tasks than Jakarta (see Table $\mathrm{x}$ ). It can interpreted that the smaller cities which has lower complexity than the big cities, have more easily in determining special budget for disaster management and building curiculum to enhance the coping capacity of community.

Table 1. The role of Government in implementing RPB

\begin{tabular}{|c|l|c|c|}
\hline No & \multicolumn{1}{|c|}{ Government Capacity } & Jakarta & Yogyakarta \\
\hline 1 & Written regulation & Yes & Yes \\
\hline 2 & Specific institution & Yes & Yes \\
\hline 3 & Early warning system & Yes & Yes \\
\hline 4 & Special budget & No & Yes \\
\hline 5 & Disaster map & No & No \\
\hline 6 & Disaster assessment & Yes & Yes \\
\hline 7 & Systematically Data & No & No \\
\hline 8 & Disaster curriculum & No & Yes \\
\hline 9 & Disaster socialization & Yes & Yes \\
\hline 10 & Integrated management between environment & Yes & Yes \\
\hline 11 & Sanagement and disaster & Yes & Yes \\
\hline 12 & Evacuation practice & Yes & Yes \\
\hline 13 & Operational Standard Procedure & Yes & Yes \\
\hline
\end{tabular}

\section{Conclusion}

The hard experiences of big disaster events in the past have made Indonesia Government realized that the disaster management should be set up in the systemic framework and integrated into the development process. It is systematic since the RPB should follow the risk mapping process, and it is integral process for development because the planning should use the program provision of development planning. The disaster management planning (RPB) has been ordered to become guidance for implementing a comprehensive disaster management program and an interface to development planning process. Based on two cities' experiences, it can be shown that the RPB process still strongly driven by government, but run inclusively. The size of the cities has a significant role in having more inclusive process of RPB. Therefore, the disaster management in Indonesia has been conducted in holistic way since already based on the planning process, not only reacted to the disaster events. 


\section{Acknowledgements}

Apart from the efforts of myself, the success of any project depends largely on the encouragement and guidelines of many others. We take this opportunity to express our gratitude to the Japan Society for the Promotion of Science JSPS through Japan-East Asia Network and Directorate General of Higher Education, Ministry of National Education, Indonesia as main supported and people who have been instrumental in the successful completion of this project. Also we would like to show our greatest appreciation to Dr. Hajime Nobuhara, Muhammad Haris. Head of Postgraduate Program, Prof. Dr. Chandra Wijaya, M.Si., M.M, Komara Djaja, SE., M.Sc., PhD as Head of Urban Studies, Postgraduate Program Universitas Indonesia. We can't say thank you enough for his tremendous support and help.

The guidance and support received from all the members who contributed and who are contributing to this project, were vital for the success of the project. I am grateful for their constant support and help.

\section{References}

[1] I. Burton, R. W. Kates and G. F. White, "The Environment as Hazard”, Second Edition, New York/London: Guilford Press, (1993).

[2] K. Hewitt, "Sustainable Disasters? Perspectives and Powers in the Discourse of Calamity", in Crush J. ed., Power of Development, London: Routledge, (1995).

[3] A. Kreimer and P. K. Freemen, "Managing Disaster Risk in Mexico, Market Incentives for Mitigation Investment", Washington, D.C.: The World Bank, (1999).

[4] M. Pelling, "The Vulnerability of Cities, Natural Disasters and Social Resilience", London: Earthscan, (2003).

[5] The Economic and Social Commission for Asia and the Pacific (ESCAP) and the International Strategy for Disaster Reduction (ISDR), “The Asia Pacific Disaster Report 2010”, (2010).

[6] Team of Urban Studies, Final Report of Risk Mapping at 9 Provinces in Indonesia, Jakarta: PT Sucofindo, (2012).

[7] M. H. Glantz, "Flashpoints Informal Planning Meeting (IPM) 4-5 April 2002: Annotated agenda with discussion results", (2002), http://www.esig.ucar.edu/flash/summary.html.

[8] E. L. F. Schipper, "Exploring Adaptation to Climate Change: A Development Perspective", (2004) June, http://www.climate-adaptation.info/wp-content/uploads/2007/08/schipper-phd-thesis-2004.pdf.

[9] http://unstats.un.org/unsd/default.htm.

[10] http://sedac.ciesin.columbia.edu/hazards/hotspots/synthesisreport.pdf.

[11] http://dibi.bnpb.go.id/DesInventar/dashboard.jsp?countrycode=id\&continue=y\&lang=ID.

[12] www.usgs.com. 